\title{
Enhancing Ductility of 1045 Nanoeutectic Steel Prepared by Aluminothermic Reaction through Annealing at $873 \mathrm{~K}$
}

\author{
Zhengning Li, Fuan Wei, Peiqing La, Hongding Wang, and Yupeng Wei \\ State Key Laboratory of Advanced Processing and Recycling of Nonferrous Metals, Lanzhou University of Technology, \\ Lanzhou 730050, China \\ Correspondence should be addressed to Peiqing La; pqla@lut.cn
}

Received 8 November 2016; Revised 24 December 2016; Accepted 4 January 2017; Published 29 January 2017

Academic Editor: Pavel Lejcek

Copyright (c) 2017 Zhengning Li et al. This is an open access article distributed under the Creative Commons Attribution License, which permits unrestricted use, distribution, and reproduction in any medium, provided the original work is properly cited.

The 1045 steel with lamellar spacing of pearlite in nanometer was prepared by aluminothermic reaction casting and annealed at $873 \mathrm{~K}\left(600^{\circ} \mathrm{C}\right)$ with different time. Microstructures of steels were investigated by X-ray diffraction (XRD), scanning electron microscope (SEM), and transmission electron microscope (TEM). Tensile properties of the steels were measured. The results showed that the lamellar spacing of the pearlite increased with the annealing time. It was found that the microstructure of steels consisted of nanocrystalline-ferrite matrix and laminar pearlite phase. The average grain sizes of the ferrite were 26.9, 27.0, 26.1, and $34.9 \mathrm{~nm}$ for the cast steel and samples annealed for 2,4 , and $6 \mathrm{~h}$, respectively. As the annealing time increased, the volume fraction of the pearlite almost remained constant, while the laminar spacing of pearlite increased from 146 to $300 \mathrm{~nm}$. The tensile and yield strength varied slightly; the elongation obviously improved. After annealing for $4 \mathrm{~h}$, the elongation increased to be $33 \%$, which was the reported highest value for the steel up to now and about twice of the conventional 1045 steel.

\section{Introduction}

Due to high strength, considerate ductility, and low production cost of the steel, it occupied about $90 \%$ of the world's metals production. Owing to potential large decrease of raw material and energy consumption in using, steels with higher strength, considerable ductility, and lower cost are attracting considerable interests $[1,2]$.

The 1045 carbon steel as an excellent structure material had been widely used in manufactures matches plate and guide pillar of the mould, moving component of the steam turbine, compressor, and pump, such as bent axle, transmission shaft, gear, and worm. The steel had high strength, good machinability, and low cost; after annealing, the steel had considerable toughness, plasticity, and abrasive resistance [36]. The improvement of ductility and tensile strength was the most concerned problem in the development of advanced 1045 carbon steel. In metals and alloys, high ductility was often accompanied by low strength, and they rarely can be enhanced simultaneously [4].

The flow stress of the carbon steels was not only connected with the volume fraction of pearlite but also with the microstructure characteristics of the individual phase constituents (which included lamellar spacing and colony size of the pearlite and grain size of the ferrite). For the case of low carbon steels with C (carbon content) $\leq 0.25 \%$, the yield strength was mainly affected by the ferrite grain size; while carbon content increased, the contribution of pearlite starts being relevant. And when $C>0.25 \%$, the lamellar spacing $(S)$ becomes important, but usually there was not a direct linear relationship between YS and UTS with $S^{-1 / 2}$ [7].

In general, strength of steels significantly increased with carbon content; while ductility largely decreased at the same time, there was no method to obtain high ductility in high carbon steel up to now. In present work, high ductility without loss of strength has been successfully obtained in 1045 carbon steel which has lamellar spacing of pearlite in nanometer without any expensive alloying elements [8-14].

\section{Methods}

Commercial ferric oxide and aluminum powders were weighted according to stoichiometry of the aluminothermic reaction (1); then carbon and silicon powders that were 
TABLE 1: The composition of the raw powder (wt.\%).

\begin{tabular}{lccccc}
\hline Raw material & $\mathrm{Fe}_{2} \mathrm{O}_{3}$ & $\mathrm{Al}$ & $\mathrm{Si}$ & $\mathrm{Fe}$ & $\mathrm{C}$ \\
\hline Weight $(\mathrm{g})$ & 55.20 & 18.63 & 0.16 & 25.77 & 0.27 \\
\hline
\end{tabular}

designed to be 0.45 and $0.25 \mathrm{wt} \%$ without $\mathrm{Mn}$ element in the produced steel were added in the reactant powders. The composition of the raw powders and purity was shown in Tables 1 and 2, respectively.

$$
\mathrm{Fe}_{2} \mathrm{O}_{3}+2 \mathrm{Al}+1.33 \mathrm{Fe}=3.33 \mathrm{Fe}+\mathrm{Al}_{2} \mathrm{O}_{3} .
$$

The powders were dry-mixed at a speed of $150 \mathrm{rpm}$ (rotation per minute) for $8 \mathrm{~h}$ using a planetary ball mill with $\mathrm{Al}_{2} \mathrm{O}_{3}$ spheres. Then the mixed powders were pressed under a uniaxial pressure of $40 \mathrm{MPa}$ as compacts in a steel tube. The substrate and the tube were ultrasonically cleaned in ethanol before using. The compacts were put on copper substrate in a reactor. A lamellar igniter of about $2 \mathrm{~g}$ was put on the surface of the pressed powders, which was given in details elsewhere [7-11]. The substrate, stainless steel jars, steel mould, and inner wall of the reactor were cleaned by ethanol before using, and the copper substrate was kept horizontal in the reactor.

The reactor was purged with argon gas at room temperature and heated to $473 \mathrm{~K}\left(200^{\circ} \mathrm{C}\right)$; then the reactor was purged again and $5 \mathrm{MPa}$ argon gas was introduced. The reactor was continually heated and the igniter was ignited at $533 \mathrm{~K}\left(260^{\circ} \mathrm{C}\right)$, and released exothermic heat started aluminothermic reaction of the reactant powders. The reactants transformed to $\mathrm{Fe}(\mathrm{C}, \mathrm{Si})$ and $\mathrm{Al}_{2} \mathrm{O}_{3}$ melts in areas where the combustion wave passed compacts. The reaction completed in a few seconds, and the products were kept in the reactor to cool down under the pressure of argon gas. The products were taken out from the reactor at room temperature and surrounding of the steel product was a gray layer of $\mathrm{Al}_{2} \mathrm{O}_{3}$. Due to the thermal expansion coefficient between the $\mathrm{Al}_{2} \mathrm{O}_{3}$ and the 1045 carbon steel being large, the binding between the carbon steel and $\mathrm{Al}_{2} \mathrm{O}_{3}$ phase was very weak, and thus $\mathrm{Al}_{2} \mathrm{O}_{3}$ phase could be removed by hands. The produced steel ingot was about $110 \mathrm{~mm}$ in diameter and $10 \mathrm{~mm}$ in height. Samples were cut from the steel ingot using wire cutting machine; they were annealed at $873 \mathrm{~K}\left(600^{\circ} \mathrm{C}\right)$ in a furnace for 2,4 , and $6 \mathrm{~h}$ and then cooled to room temperature in the furnace, respectively.

The cross sections of the samples were polished with sand paper and ultrasonically cleaned in ethanol for ten minutes and then examined by D8 X-ray diffraction (XRD) using Cu $\mathrm{K} \alpha$ radiation. Polished cross section of the steels was etched by $4 \%$ nitric acid alcohol for $45 \mathrm{~s}$, subsequently, examined by a JSM-6700F field emission scanning electron microscope (FESEM).

Lamellar spacing of the pearlite without and with annealed at different time was measured by Image-Pro plus software from high magnification SEM pictures. We drew a line which is perpendicular with the lamellar pearlite in high magnification SEM picture and measured the length of this line $\left(l_{0}\right)$ and then counted the number of the lamellar pearlites $(n)$ which intersects with the line; lamellar spacing of the pearlite includes one lamellar ferrite and one lamellar
TABLE 2: Chemical composition of the raw powders (wt.\%).

\begin{tabular}{lcc}
\hline Raw material & Purity & Impurity \\
\hline $\mathrm{Fe}_{2} \mathrm{O}_{3}$ & $>99 \%$ & $\mathrm{Cl}^{-}, \mathrm{SO}_{4}{ }^{-2}, \mathrm{~N}, \mathrm{Cu}$ \\
$\mathrm{Al}$ & $>99 \%$ & $\mathrm{~N}, \mathrm{Si}, \mathrm{Fe}, \mathrm{Cu}$ \\
$\mathrm{Fe}$ & $>99.9 \%$ & $\mathrm{P}, \mathrm{Si}, \mathrm{Cu}$ \\
$\mathrm{Si}$ & $>99.9 \%$ & $\mathrm{Fe}, \mathrm{Al}, \mathrm{Ca}, \mathrm{Cu}$ \\
$\mathrm{C}$ & $>99.9 \%$ & $\mathrm{SiO}_{2}, \mathrm{Al}_{2} \mathrm{O}_{3}, \mathrm{FeO}, \mathrm{CaO}, \mathrm{P}_{2} \mathrm{O}_{5}, \mathrm{CuO}$ \\
\hline
\end{tabular}

cementite; the lamellar spacing of the pearlite was $S=l_{0} / n$. The lamellar spacing of the pearlite was an average value of ten high magnification SEM pictures; the standard deviation was less than $5 \%$.

Sheet specimens cut from the rolled steels were grounded into thin foils with less than $100 \mu \mathrm{m}$ in thickness by hands and then punched into plates with a diameter of $3 \mathrm{~mm}$ by a puncher. The plates were thinned electrolytically by a twinjet electropolishing device and were examined on a JEM2010 transmission electron microscope (TEM) with voltage of $200 \mathrm{kV}$. The electrolyte was a solution of 2 vol. $\%$ perchloric acid in ethanol.

Tensile specimens that were $17 \mathrm{~mm}$ in length were cut from the steels. The tensile tests were performed on the Shimadzu AT10 t tester with a crossing speed of $0.2 \mathrm{~mm} \mathrm{~min}^{-1}$ and repeated three times; final value was an average of the three times; the standard deviation was less than $5 \%$.

\section{Results}

XRD pattern of the 1045 carbon steel without and with annealing at $873 \mathrm{~K}\left(600^{\circ} \mathrm{C}\right)$ for different time is shown in Figure 1; the peaks correspond to ferrite phase, but the peaks of cementite phase are not detected. The average grain size of the ferrite of the cast 1045 steel and the steel annealing with different time was calculated, which was deduced from the Scherrer equation (2):

$$
d=\frac{K \lambda}{B \cos \theta}
$$

where $d, \lambda$, and $\theta$ represent the average grain size, the wavelength of characteristic X-ray, and the diffraction angle, respectively. $K$ is a constant, and $B$ is the half width of the broadening $\mathrm{X}$-ray diffraction by virtue of grain refinement. The average grain size of the ferrite without and with annealing at $873 \mathrm{~K}\left(600^{\circ} \mathrm{C}\right)$ for different time is $26.9,27.0$, 26.1, and $34.9 \mathrm{~nm}$, respectively. It remains nearly constant before annealing at $600^{\circ} \mathrm{C}$ with $6 \mathrm{~h}$ and then increases with the annealing $6 \mathrm{~h}$. Typical FE-SEM micrographs of the 1045 carbon steel without and with annealing at $873 \mathrm{~K}\left(600^{\circ} \mathrm{C}\right)$ for different time are shown in Figures 2-5; the phase that looks like island is the pearlite and the other is the ferrite in the low magnification SEM micrographs (Figures 2(a)-5(a)). It also can be demonstrated by energy dispersive spectrometer (EDS) elements analysis of the cast 1045 steel in Figure 6; the area with higher carbon content is pearlite phase, and the other area is ferrite phase. The volume fraction of the pearlite in the steels without and with annealing at 2, 4, 


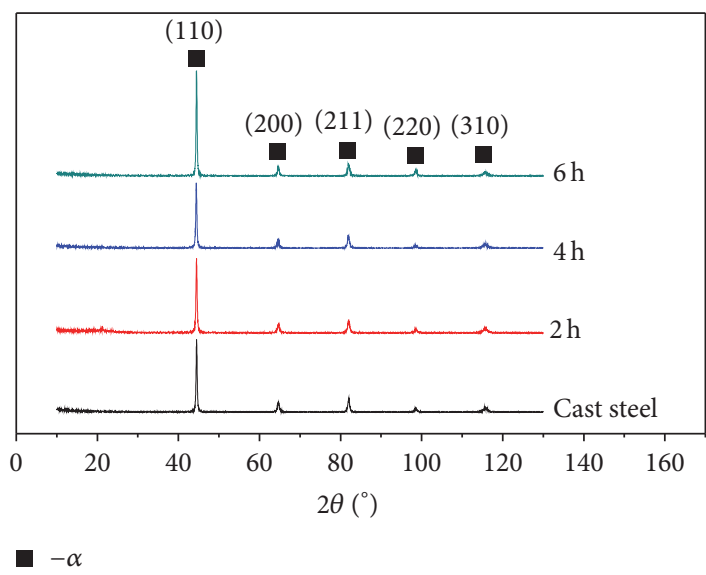

FIGURE 1: XRD pattern of the 1045 carbon steel without and with annealing at $873 \mathrm{~K}\left(600^{\circ} \mathrm{C}\right)$ with different time.

and $6 \mathrm{~h}$ is calculated by Image-Pro plus software from low magnification SEM pictures are about 22, 20, 22, and 23\%; the result showed that the volume fraction of the pearlite of the steels is not changed after annealing. Figures 2(b)-5(b) are higher magnification of the A region in Figures 2(a)-5(a), respectively. Figures 2(c)-5(c) are the higher magnification of the $B$ region in Figures 2(b)-5(b), respectively. The measured lamellar spacing of the pearlite in 1045 steels increases with the annealing time, without and with annealing at 2, 4, and $6 \mathrm{~h}$, is about $146,172,255$, and $300 \mathrm{~nm}$, respectively. Bright field TEM micrographs of the pearlite in steels without and with annealing at $873 \mathrm{~K}\left(600^{\circ} \mathrm{C}\right)$ with different time are shown in Figure 7; the lamellar pearlites are composed of black stripes and gray matrix; the black stripes are cementite and the gray matrix is the ferrite, which can be demonstrated from SAED (selected area electron diffraction) image of the pearlite in steel with annealing at $873 \mathrm{~K}\left(600^{\circ} \mathrm{C}\right)$ for $2 \mathrm{~h}$ in Figure 8 . Figures $8(\mathrm{~b})$ and $8(\mathrm{~d})$ are the SAED image of the red region in Figures 8(a) and 8(c), respectively; the SAED patterns are indexed to be cementite and ferrite, respectively, and the weak diffraction halo indicates the presence of a small amount of noncrystalline phase. The lamellar spacing of the pearlite measured from bright field of TEM micrographs, and the result complies with the value measured from SEM micrographs.

Tensile curves of the 1045 steel without and with annealing at $873 \mathrm{~K}\left(600^{\circ} \mathrm{C}\right)$ for different time are shown in Figure 9 and summarized in Table 3 . The elongation increases from $15 \%$ of the cast steel to $33 \%$ when the annealing time is $4 \mathrm{~h}$, and the tensile and yield strength of the steels almost are not changed with the annealing time increases; when the annealing time increases to $6 \mathrm{~h}$, the elongation of the steel decreases to $22 \%$; the tensile and yield strength of the steel decrease a little. The steel with annealing at $873 \mathrm{~K}\left(600^{\circ} \mathrm{C}\right)$ for $4 \mathrm{~h}$ has highest elongation of $33 \%$. The elongation is the highest value in 1045 steels, and about twice for conventional 1045 carbon steel but the strength of them is the same [13].

The fracture appearance of 1045 carbon steels without and with annealing at $873 \mathrm{~K}\left(600^{\circ} \mathrm{C}\right)$ with different time is shown in Figure 10; fracture surface of the cast steel is uneven
TABLE 3: Tensile properties of the 1045 steel without and with annealing for different time.

\begin{tabular}{lccc}
\hline & $\begin{array}{c}\text { Tensile } \\
\text { strength } \\
(\mathrm{MPa})\end{array}$ & $\begin{array}{c}\text { Yield } \\
\text { strength } \\
(\mathrm{MPa})\end{array}$ & $\begin{array}{c}\text { Total } \\
\text { elongation } \\
(\%)\end{array}$ \\
\hline $\begin{array}{l}\text { The cast } 1045 \\
\text { steel }\end{array}$ & 490 & 265 & 16 \\
$2 \mathrm{~h}$ & 483 & 264 & 25 \\
$4 \mathrm{~h}$ & 488 & 267 & 33 \\
$6 \mathrm{~h}$ & 448 & 255 & 22 \\
\hline
\end{tabular}

and like lamellar tearing, when the steel is annealed at $873 \mathrm{~K}$ $\left(600^{\circ} \mathrm{C}\right)$ for $4 \mathrm{~h}$, there are a lot of dimples that appear on the fracture surface of the steel.

\section{Discussions}

During the process of aluminothermic reaction casting, the temperature of the products was calculated to be about $3040 \mathrm{~K}\left(2767^{\circ} \mathrm{C}\right)$ and the melts were superheated, and it led to a large super cooling degree in solidification process [15]. The melt was cleaned by the large super heating. Therefore, the austenite nucleation rate was very high in the solidification process. And it was beneficial to get much smaller austenite grains; the interfacial area per unit volume increased significantly. It could provide more pearlite nucleation position during the transformation of austenite to pearlite. Thus, the pearlite lamellar spacing was small in nanometer [16].

The pearlite consists of lamellar ferrite and lamellar cementite; the carbon content of them is largely different; the lamellar spacing of the pearlite was determined by carbon diffuses extent; the longer the annealing time is, the more favorable it is for the diffusion of carbon atoms, and the lamellar spacing of the pearlite increased obviously. Therefore, lamellar spacing of the pearlite increased with the annealing time. Due to the pearlite lamellar spacing of the cast steel prepared by aluminothermic reaction casting method was smaller than the conventional 1045 steels in nanometer; the free energy of grain boundary was high, and there was lack of stability of grains; the carbon diffused more fast and lamellar spacing of the pearlite increased faster than the micrometer lamellar spacing steels [17].

The elongation of the steel was greatly enhanced from $16 \%$ to $33 \%$ through annealing at $873 \mathrm{~K}\left(600^{\circ} \mathrm{C}\right)$ in comparison to cast steel. There were three major reasons about the improvement of the ductility. At first, large thermal stress formed in the process of the cast steel solidification owing to the fast cooling rate of melts metal; the thermal expansion coefficient between the ferrite and cementite in the pearlite is different. The stress was released with increase of annealing time, which can be demonstrated by XRD in Figure 2; taking (110) peak, for example, the distance of crystal face (d) of the steels without and with annealing at different time and the standard distance of crystal face of the steel without any stress were calculated by software Jade 6; the difference between them was given in Table 4 . The smaller the difference is, the more the stress is relieved completely. 


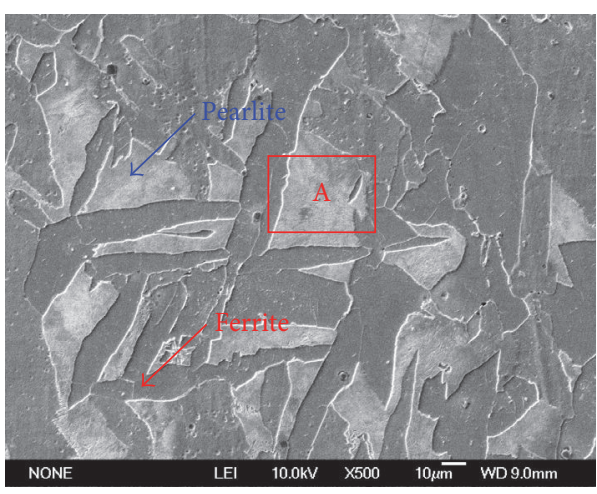

(a)

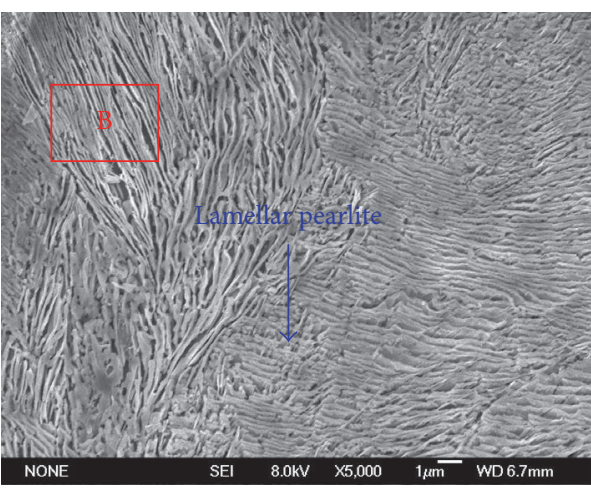

(b)

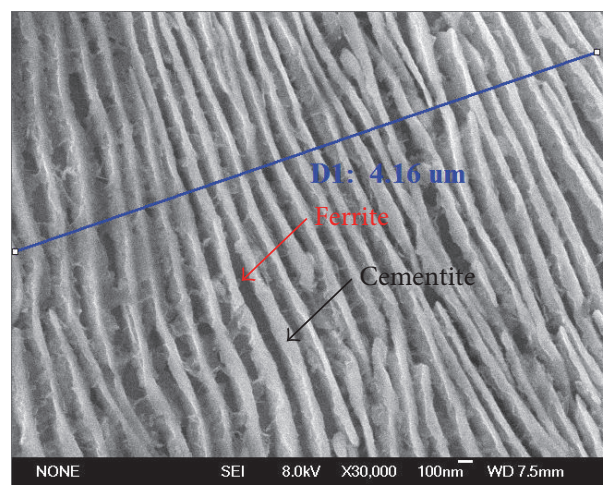

(c)

FIGURE 2: Typical FE-SEM micrographs of the cast 1045 carbon steel prepared by the aluminothermic reaction casting ((b) is the higher magnification of the A region in (a); (c) is the higher magnification of the $B$ region in (b)).

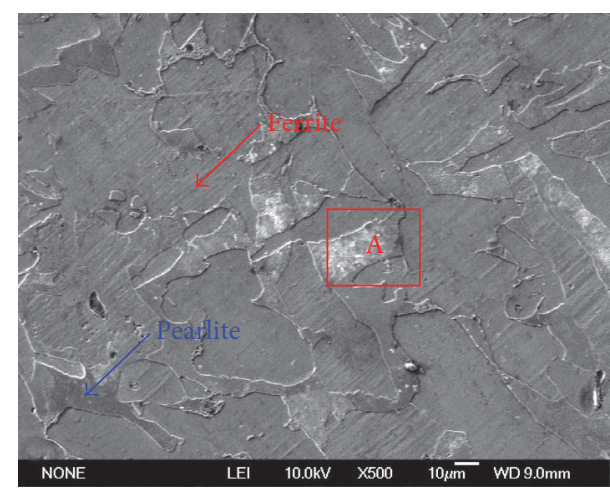

(a)

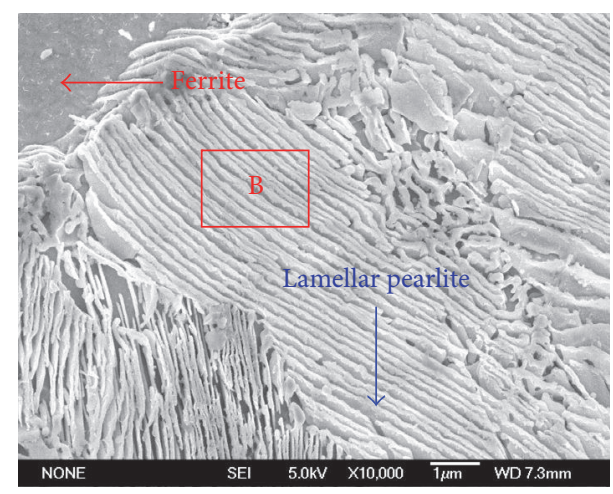

(b)

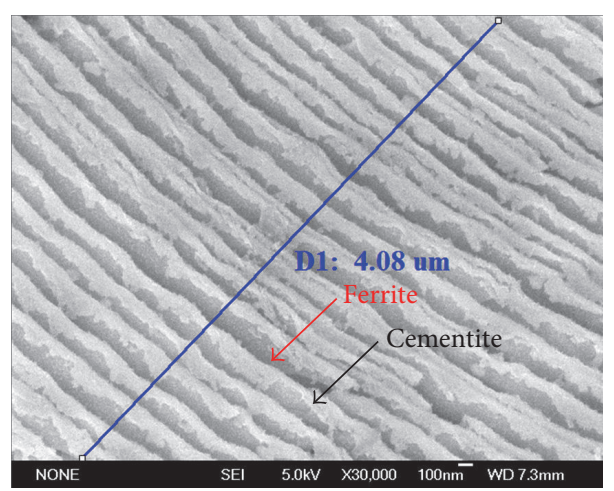

(c)

FIGURE 3: Typical FE-SEM micrographs of the 1045 carbon steel after annealing at $873 \mathrm{~K}\left(600^{\circ} \mathrm{C}\right)$ for $2 \mathrm{~h}((\mathrm{~b})$ is the higher magnification of the A region in (a); (c) is the higher magnification of the $B$ region in (b)). 


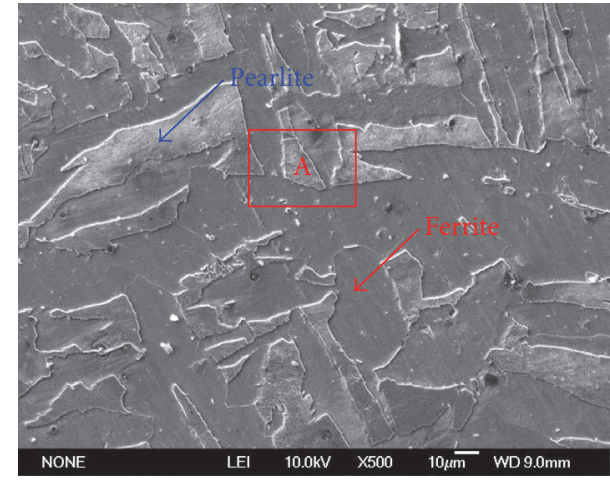

(a)

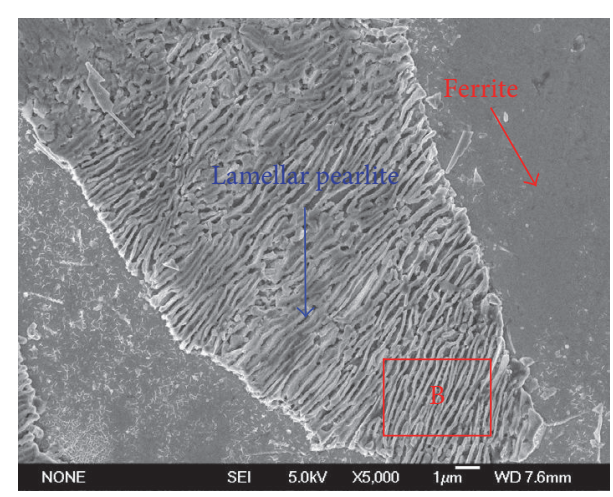

(b)

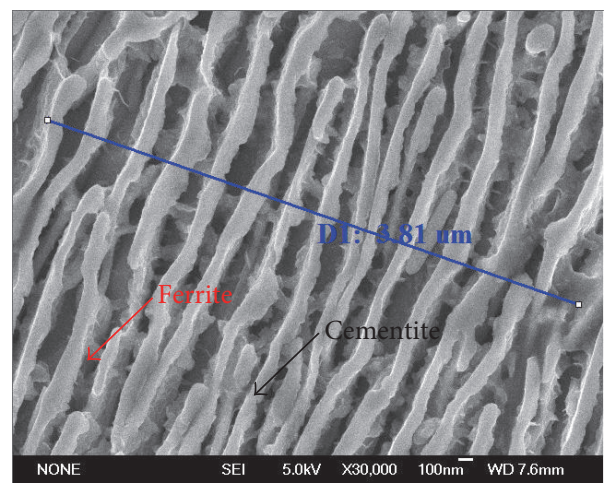

(c)

FIGURE 4: Typical FE-SEM micrographs of the 1045 carbon steel after annealing at $873 \mathrm{~K}\left(600^{\circ} \mathrm{C}\right)$ for $4 \mathrm{~h}((\mathrm{~b})$ is the higher magnification of the A region in (a); (c) is the higher magnification of the $B$ region in (b)).

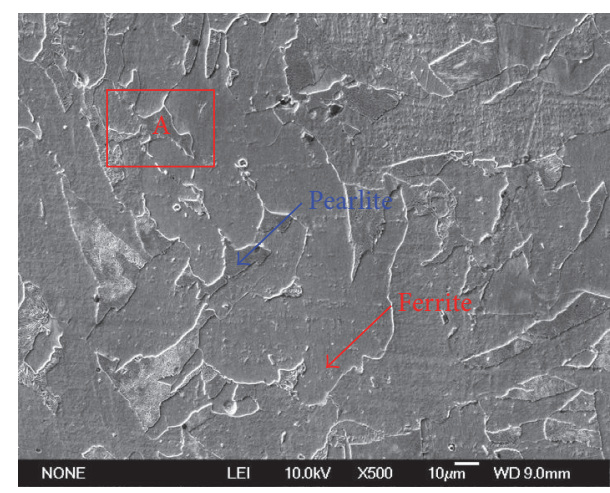

(a)

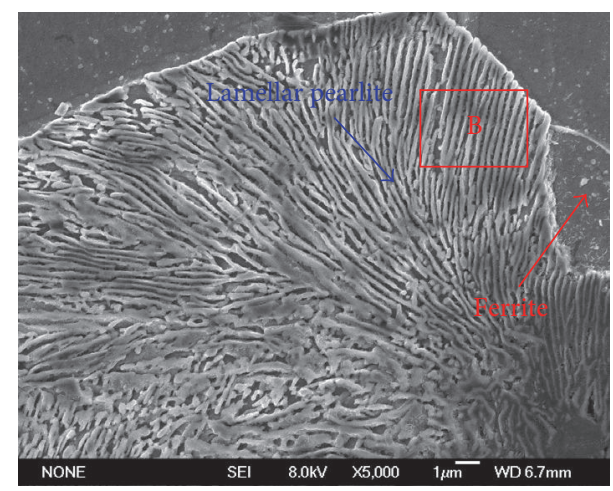

(b)

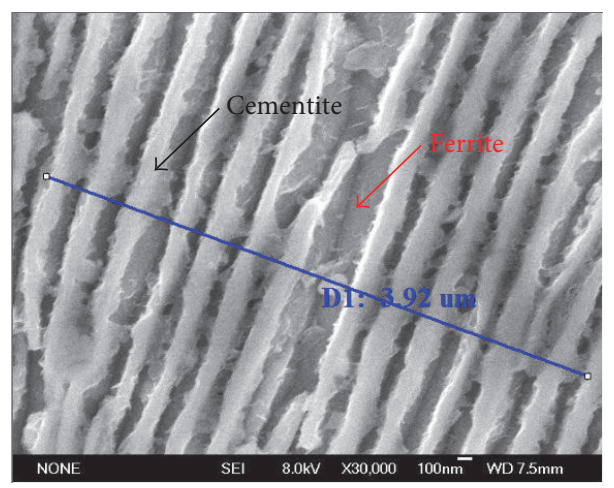

(c)

FIGURE 5: Typical FE-SEM micrographs of the 1045 carbon steel after annealing at $873 \mathrm{~K}\left(600^{\circ} \mathrm{C}\right)$ for $6 \mathrm{~h}((\mathrm{~b})$ is the higher magnification of the A region in (a); (c) is the higher magnification of the $B$ region in (b)). 


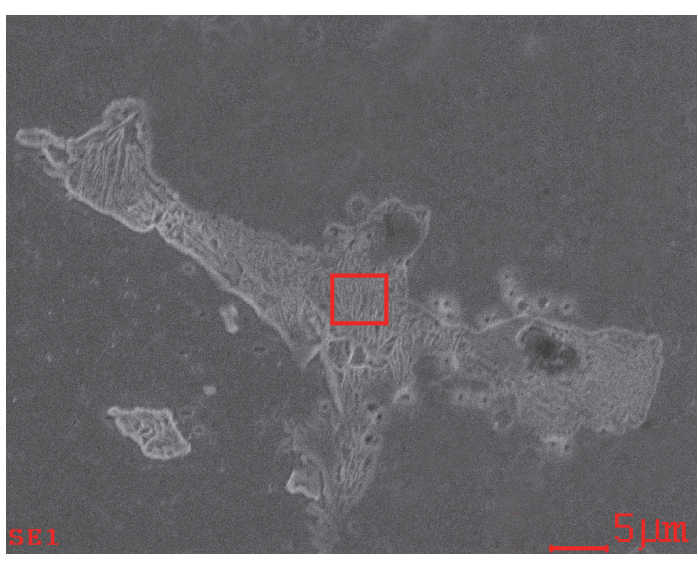

(a)

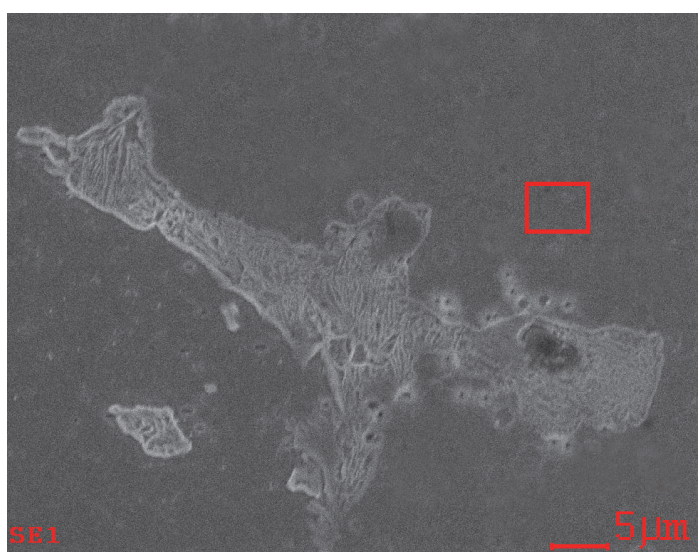

(c) c:ledax32\genesis \genmaps.spc 06-Apr-2014 10:48:50

$<$ Pt. 2 Spot $>\quad$ LSecs : 28

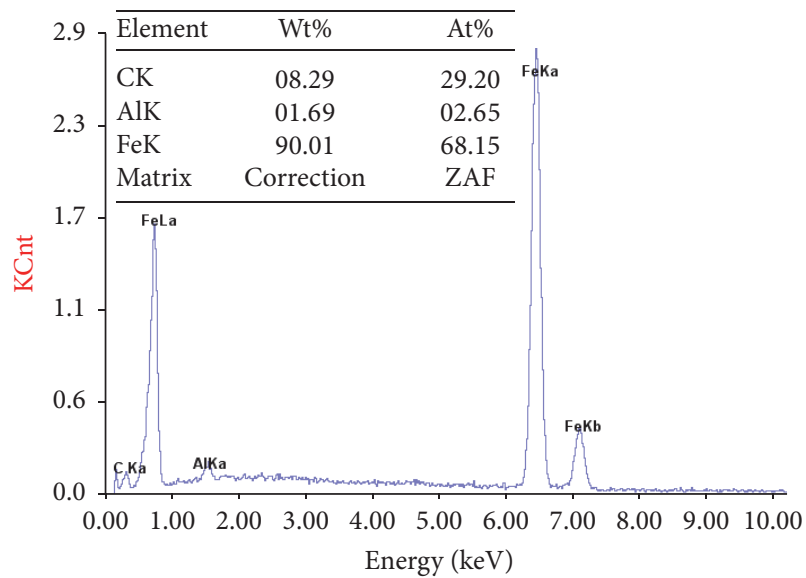

(b)

c:ledax32।genesis|genmaps.spc $\quad$ 06-Apr-2014 10:51:26 $<$ Pt. 2 Spot $>$

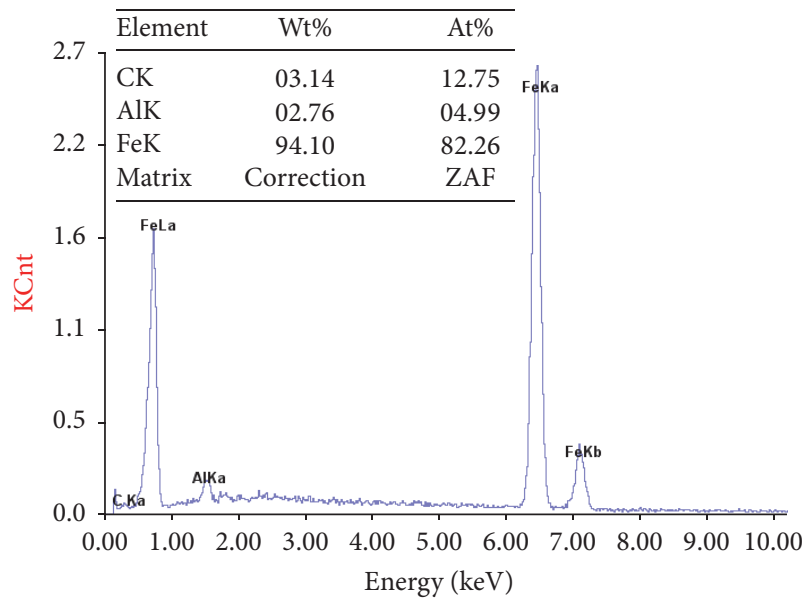

(d)

FIGURE 6: EDS elements analysis of the cast 1045 steel ((b) is correspondence of red region in (a); (d) is correspondence of red region in (c)).

Secondly, there is a small amount of the amorphous phase in the cast steel. The amorphous phase transforms into the nanocrystalline phase when the specimen was annealed at $873 \mathrm{~K}\left(600^{\circ} \mathrm{C}\right)$. Thirdly, nanograined/ultrafine-grained steel exhibited unusual deformation behavior compared with the fine-grained steel, and tensile ductility was is low relatively. For nanograined steel, during deformation, dislocations are trapped at grain boundaries; the time for dislocations to move to grain boundaries is shorter than the time of tensile test. This decrease in dislocation density reduces accumulation of dislocations inside the grains and consequently leads to less work hardening when compared with corresponding steels of coarse grain size. Grain refinement also leads to reduced work hardening capacity. As a result, plastic instability (necking) occurs at an early stage during tensile test, which results in limited uniform elongation in cast steels. The variation of tensile strength, yield strength, and percent elongation with the inverse of the square root of interlamellar spacing $(S)$ was shown in Figure 11. After annealing for $4 \mathrm{~h}$, although the grain size of ferrite remained constant, lamellar spacing of the steel increasing as $255 \mathrm{~nm}$ is also smaller than conventional microstructure, and the thermal stress was relieved. The plastic deformation was more uniform and the stress concentration was much decreased compared to the steel with conventional microstructure [6]. In addition, under the action of external stress, cracks were nucleated and grew in the cementite phase which was hard and brittle. The smaller lamellar spacing resulted in more interface area of ferrite and cementite phase in the pearlite, which was resistant to crack propagation owing to the deflection of crack at the interface. Therefore, the elongation of the steels was increased after annealing $[4,7,18,19]$. For the mechanical properties of the specimens, the yield strength and tensile strength are almost invariable with increase of the annealing time, which is attributed to the few increase in the lamellar spacing of the pearlite and the grain size of 


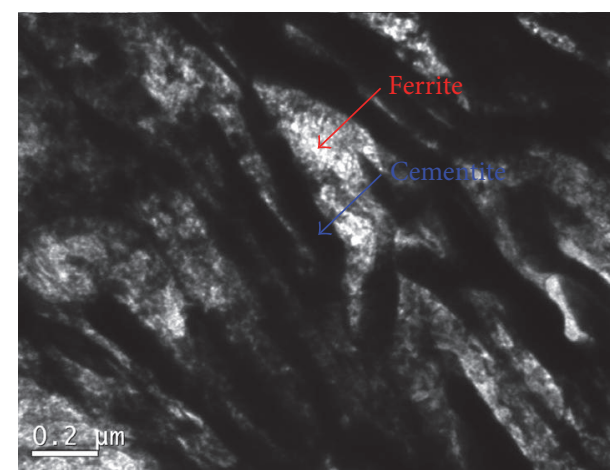

(a)

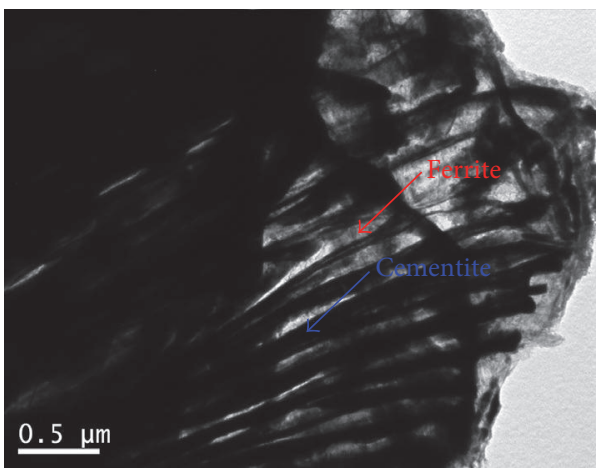

(c)

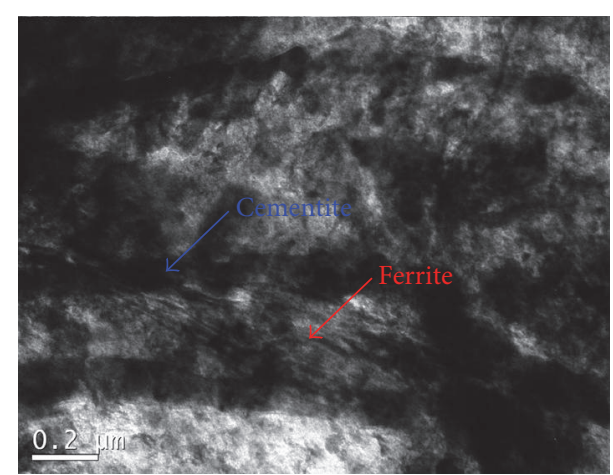

(b)

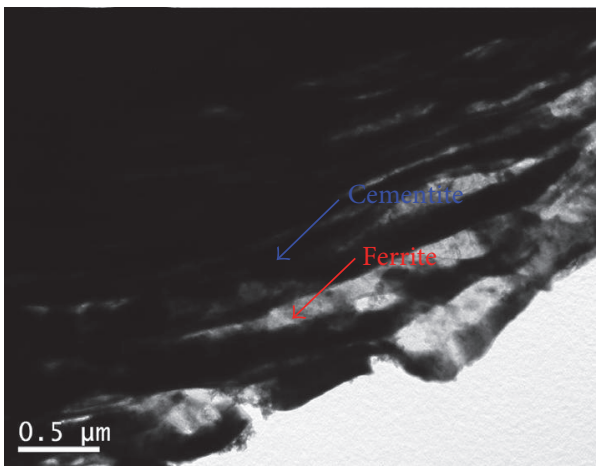

(d)

Figure 7: Bright field TEM micrographs of the pearlite in 1045 carbon steel without (a) and with annealing at $873 \mathrm{~K}\left(600^{\circ} \mathrm{C}\right)$ for $2 \mathrm{~h}(\mathrm{~b}), 4 \mathrm{~h}$ $(\mathrm{c})$, and $6 \mathrm{~h}(\mathrm{~d})$.

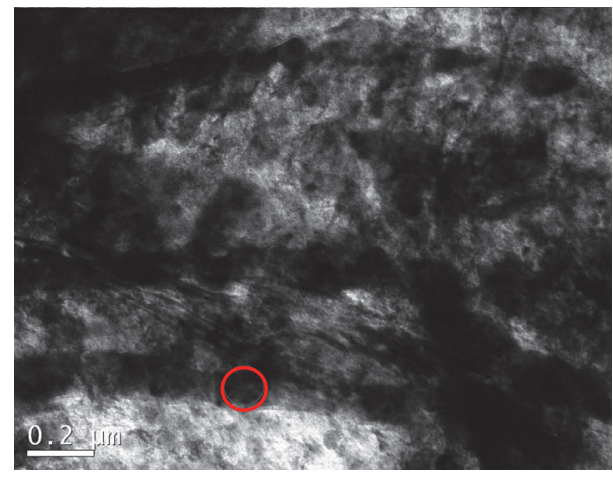

(a)

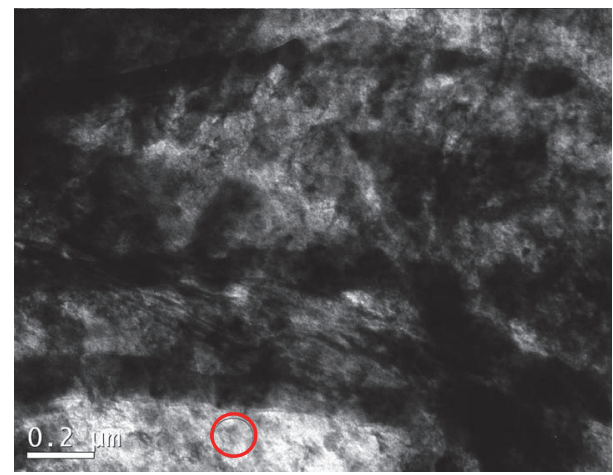

(c)

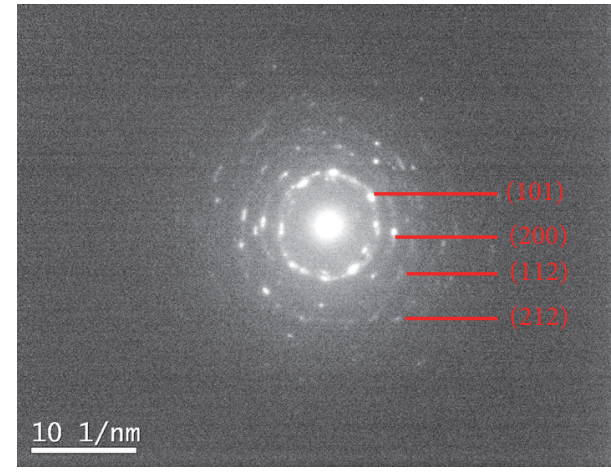

(b)

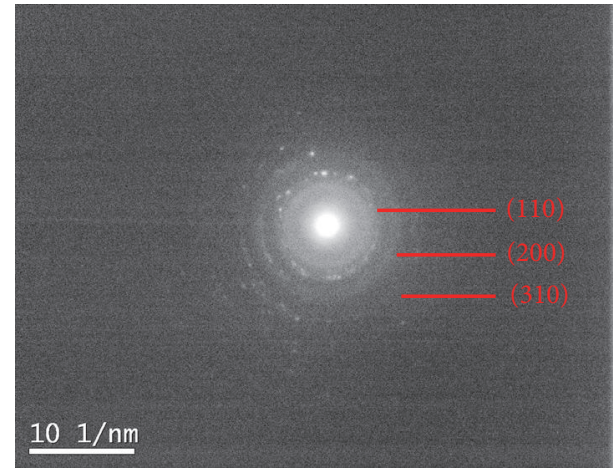

(d)

FIGURE 8: SAED image of the pearlite in 1045 carbon steel with annealing at $873 \mathrm{~K}\left(600^{\circ} \mathrm{C}\right)$ for $2 \mathrm{~h}$. 


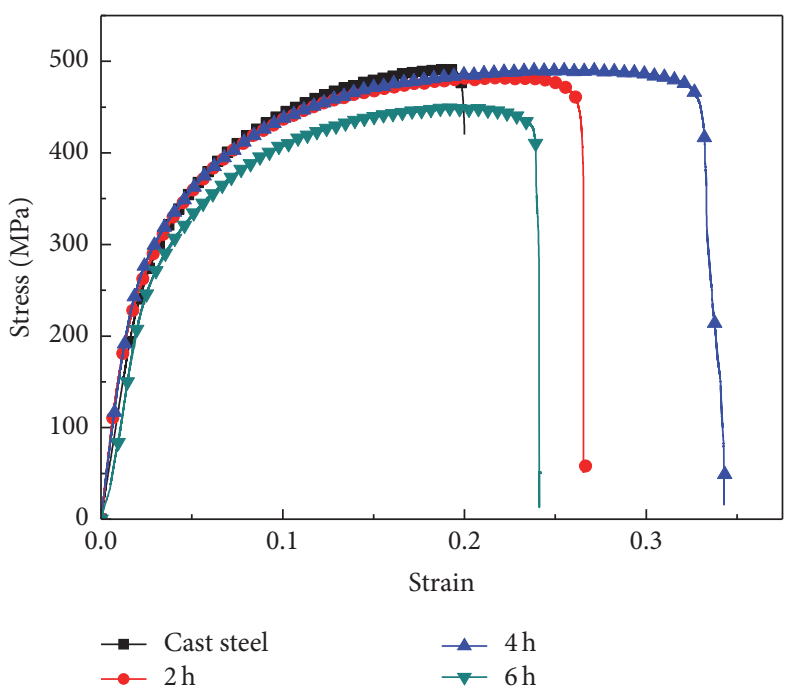

(a)

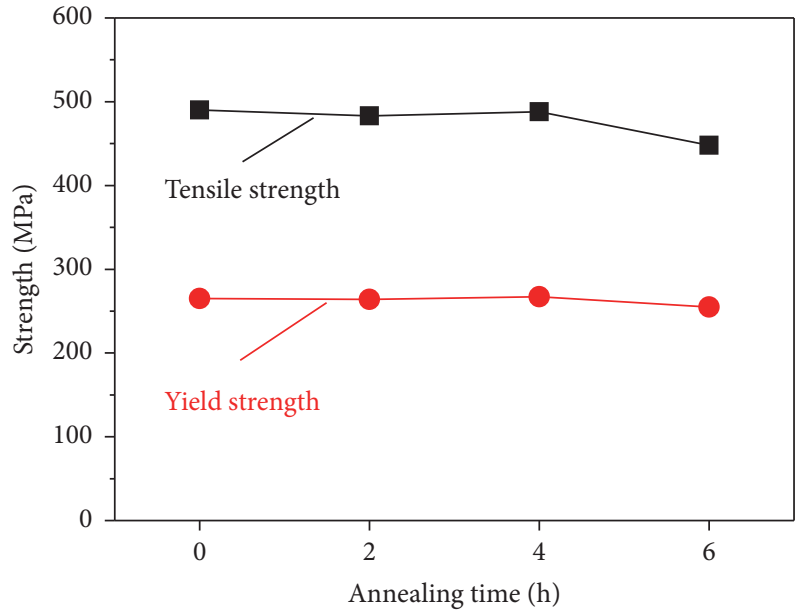

(b)

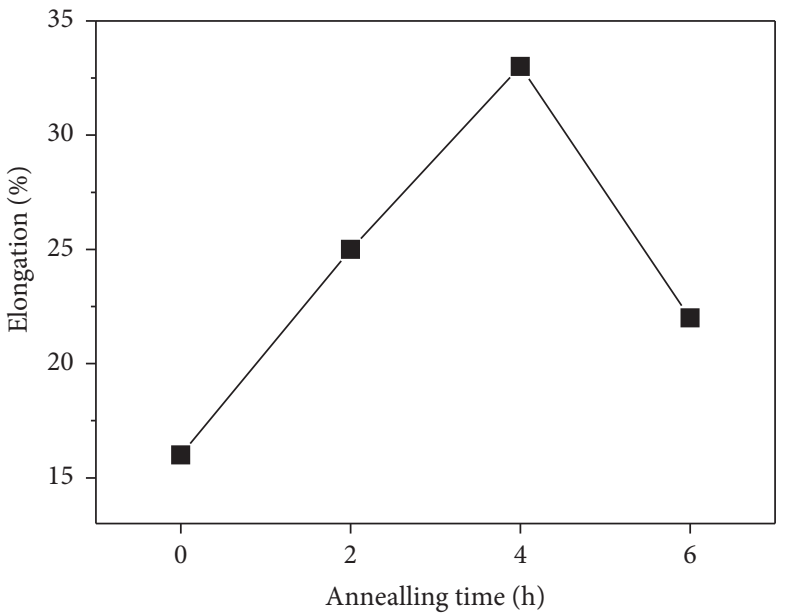

(c)

Figure 9: Tensile stress-strain curves (a), tensile and yield strength (b), and elongation rate (c) of the 1045 steel without and with annealing at $873 \mathrm{~K}\left(600^{\circ} \mathrm{C}\right)$ for different time.

ferrite. However, after annealing for $6 \mathrm{~h}$, the elongation of the steel was decreased, the lamellar spacing of the pearlite and the grain size of ferrite increased sharply, the dislocation movement became easier, but the interface between lamellar ferrite and lamellar cementite was reduced, which decreased the resistance to crack propagation by crack deflection at the interface, and the elongation was decreased. The plastic deformation was always associated with the free movement of dislocations. When lamellar spacing of the pearlite was larger than $255 \mathrm{~nm}$ and the ferrite in the pearlite was softer than cementite, it was also deformed during the course of pearlite deformation; therefore, dislocations move more freely in the ferrite zone; consequently, it results in tensile strength decreasing observably $[4,8,20,21]$.

\section{Conclusions}

The lamellar spacing of pearlite increasing with the annealing time, without and with annealing at 2, 4, and $6 \mathrm{~h}$ was about
TABLE 4: The $d$ values (distance of crystal face) of the (110) peak of the steels without and with annealing at different time, the standard $d$ value of (110) peak, and the difference between them.

\begin{tabular}{lccc}
\hline & $d\left(10^{-1} \mathrm{~nm}\right)$ & $\begin{array}{c}\text { Standard } d \\
\left(10^{-1} \mathrm{~nm}\right)\end{array}$ & $\begin{array}{c}|\Delta d| \\
\left(10^{-1} \mathrm{~nm}\right)\end{array}$ \\
\hline $\begin{array}{l}\text { The cast 1045 } \\
\text { steel }\end{array}$ & 2.0370 & 2.0262 & 0.0108 \\
$2 \mathrm{~h}$ & 2.0379 & 2.0262 & 0.0117 \\
$4 \mathrm{~h}$ & 2.0352 & 2.0262 & 0.0090 \\
$6 \mathrm{~h}$ & 2.0351 & 2.0262 & 0.0089 \\
\hline
\end{tabular}

$146,172,255$, and $300 \mathrm{~nm}$. When the annealing time is less than or equal to $4 \mathrm{~h}$, the tensile and yield strength of the steel almost were not changed with the annealing time increasing; after annealing at $6 \mathrm{~h}$, the tensile and yield strength of the steel decreased a little. The elongation of the steel increased first and then decreased; after annealing at $4 \mathrm{~h}$, the elongation 


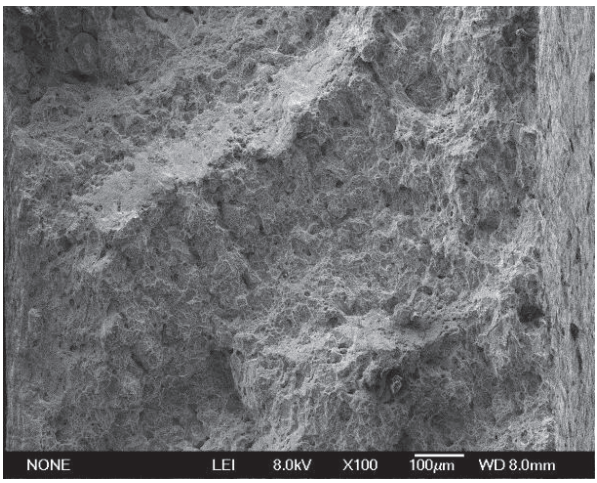

(a)

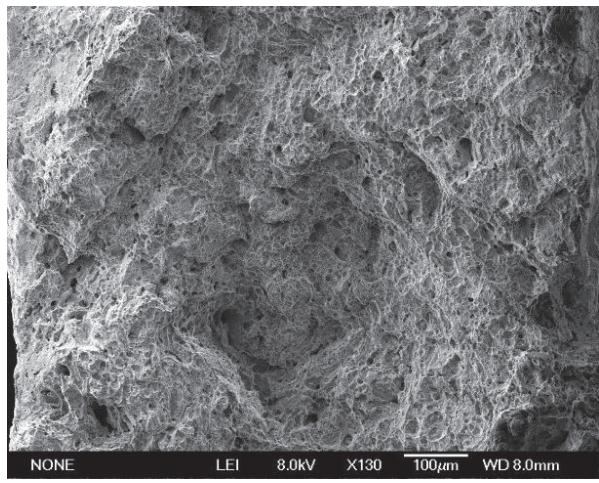

(c)

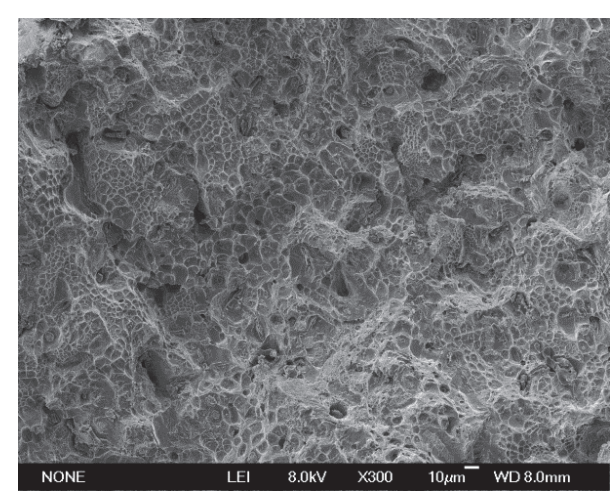

(b)

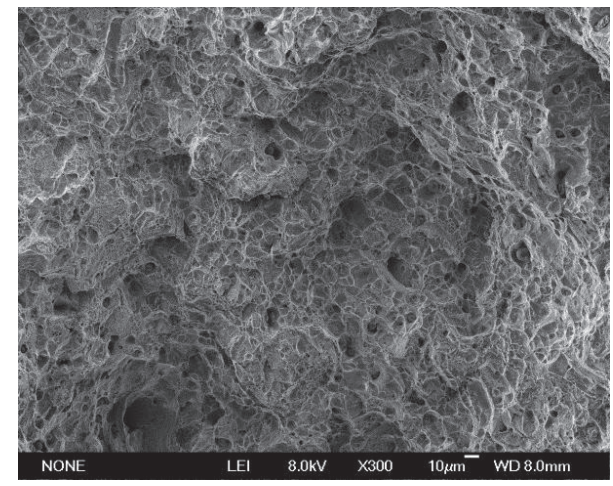

(d)

FIGURE 10: The fracture appearance of 1045 carbon steel without and with annealing at $873 \mathrm{~K}\left(600^{\circ} \mathrm{C}\right)$ for different time: macrograph $(\mathrm{a})$ and microscopy (b) of cast steel; macrograph (c) and microscopy (d) of the steel annealed at $873 \mathrm{~K}\left(600^{\circ} \mathrm{C}\right)$ for $4 \mathrm{~h}$.

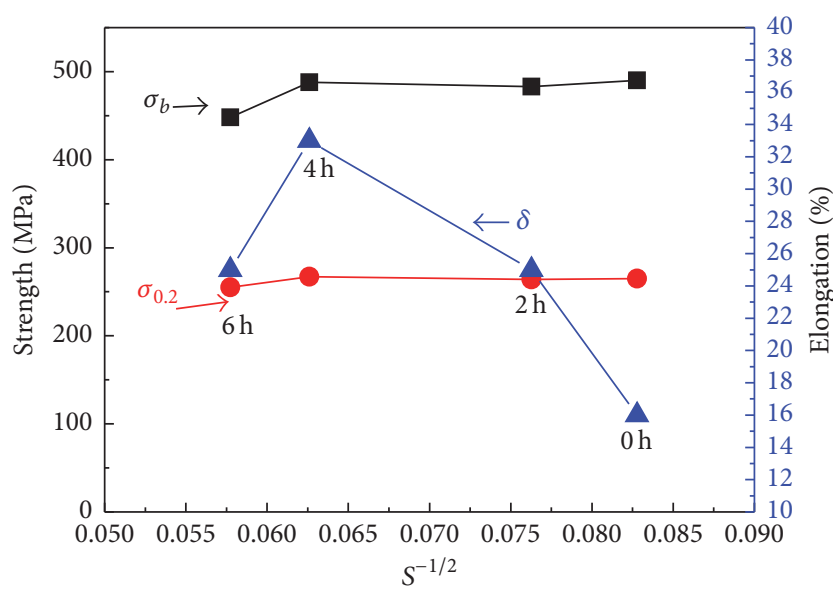

FIGURE 11: The variation of tensile strength, yield strength, and percent elongation with the inverse of the square root of interlamellar spacing, $S$.

increased from $15 \%$ of the cast steel to $33 \%$. The steel annealed at $873 \mathrm{~K}\left(600^{\circ} \mathrm{C}\right)$ for $4 \mathrm{~h}$ has the highest elongation of $33 \%$ and the tensile strength was about $488 \mathrm{MPa}$; the elongation value was about twice of the conventional 1045 steel whereas the strength remained constant. Therefore, this is a better route to enhance the ductility of 1045 nanoeutectic steel prepared by aluminothermic reaction, but it does not lose strength.

\section{Competing Interests}

The authors declare that there is no conflict of interests regarding the publication of this paper.

\section{Acknowledgments}

This work is supported by the National Natural Science Foundation of China (51164022) and Gansu Provincial Science and Technology Support Program (1304GKCA027).

\section{References}

[1] G. Buzzichelli and E. Anelli, "Present status and perspectives of European research in the field of advanced structural steels," ISIJ International, vol. 42, no. 12, pp. 1354-1363, 2002.

[2] R. Song, D. Ponge, D. Raabe, J. G. Speer, and D. K. Matlock, "Overview of processing, microstructure and mechanical properties of ultrafine grained bcc steels," Materials Science and Engineering A, vol. 441, no. 1-2, pp. 1-17, 2006.

[3] H. W. Song, S. R. Guo, and Z. Q. Hu, "Coherent polycrystal model for the inverse Hall-Petch relation in nanocrystalline materials," Nanostructured Materials, vol. 11, no. 2, pp. 203-210, 1999.

[4] K. S. Kumar, H. Van Swygenhoven, and S. Suresh, "Mechanical behavior of nanocrystalline metals and alloys," Acta Materialia, vol. 51, no. 19, pp. 5743-5774, 2003. 
[5] Y.Zhao, T. Topping, J. F. Bingert et al., "High tensile ductility and strength in bulk nanostructured nickel," Advanced Materials, vol. 20, no. 16, pp. 3028-3033, 2008.

[6] S. Ramtani, G. Dirras, and H. Q. Bui, "A bimodal bulk ultrafine-grained nickel: experimental and micromechanical investigations," Mechanics of Materials, vol. 42, no. 5, pp. 522-536, 2010.

[7] M.-C. Zhao, T. Hanamura, F. Yin, H. Qiu, and K. Nagai, "Formation of bimodal-sized structure and its tensile properties in a warm-rolled and annealed ultrafine-grained ferrite/cementite steel," Metallurgical and Materials Transactions A, vol. 39, no. 7, pp. 1691-1701, 2008.

[8] F. Khodabakhshi, M. Kazeminezhad, and A. H. Kokabi, “Constrained groove pressing of low carbon steel: nano-structure and mechanical properties," Materials Science and Engineering A, vol. 527, no. 16-17, pp. 4043-4049, 2010.

[9] E. Ghassemali, A. Kermanpur, and A. Najafizadeh, "Microstructural evolution in a low carbon steel during cold rolling and subsequent annealing," Journal of Nanoscience and Nanotechnology, vol. 10, no. 9, pp. 6177-6181, 2010.

[10] S. M. Hosseini, A. Najafizadeh, and A. Kermanpur, "Producing the nano/ultrafine grained low carbon steel by martensite process using plane strain compression," Journal of Materials Processing Technology, vol. 211, no. 2, pp. 230-236, 2011.

[11] K.-T. Park, Y.-S. Kim, J. G. Lee, and D. H. Shin, “Thermal stability and mechanical properties of ultrafine grained low carbon steel," Materials Science and Engineering A, vol. 293, no. 1-2, pp. 165-172, 2000.

[12] C. Mangler, C. Gammer, H. P. Karnthaler, and C. Rentenberger, "Structural modifications during heating of bulk nanocrystalline FeAl produced by high-pressure torsion," Acta Materialia, vol. 58, no. 17, pp. 5631-5638, 2010.

[13] V. L. Tellkamp, E. J. Lavernia, and A. Melmed, "Mechanical behavior and microstructure of a thermally stable bulk nanostructured $\mathrm{Al}$ alloy," Metallurgical and Materials Transactions A, vol. 32, no. 9, pp. 2335-2343, 2001.

[14] T. B. Holland, I. A. Ovid'ko, H. Wang, and A. K. Mukherjee, "Elevated temperature deformation behavior of spark plasma sintered nanometric nickel with varied grain size distributions," Materials Science and Engineering A, vol. 528, no. 2, pp. 663-671, 2010.

[15] P. La, F. Wei, S. Hu, C. Li, and Y. Wei, "White cast iron with a nano-eutectic microstructure and high tensile strength and considerable ductility prepared by an aluminothermic reaction casting," Materials Science and Engineering A, vol. 561, pp. 317320, 2013.

[16] H. Wang, D. Zhu, C. Zou, and Z. Wei, "Effect of high pressure on the lamellar spacing and mechanical properties of Ti-48Al alloy," Rare Metal Materials and Engineering, vol. 41, no. 1, pp. 42-44, 2012.

[17] F. L. Lian, H. J. Liu, J. J. Sun et al., "Ultrafine grain effect on pearlitic transformation in hypereutectoid steel," Journal of Materials Research, vol. 28, no. 5, pp. 757-765, 2013.

[18] F. Khodabakhshi and M. Kazeminezhad, "The annealing phenomena and thermal stability of severely deformed steel sheet," Materials Science and Engineering A, vol. 528, no. 15, pp. 52125218, 2011.

[19] C. C. Koch, R. O. Scattergood, M. Saber, and H. Kotan, "High temperature stabilization of nanocrystalline grain size: thermodynamic versus kinetic strategies," Journal of Materials Research, vol. 28, no. 13, pp. 1785-1791, 2013.
[20] T. S. Wang, Z. Li, B. Zhang, X. J. Zhang, J. M. Deng, and F. C. Zhang, "High tensile ductility and high strength in ultrafinegrained low-carbon steel," Materials Science and Engineering A, vol. 527, no. 10-11, pp. 2798-2801, 2010.

[21] P. Zhang, S. X. Li, and Z. F. Zhang, "General relationship between strength and hardness," Materials Science and Engineering $A$, vol. 529, no. 1, pp. 62-73, 2011. 

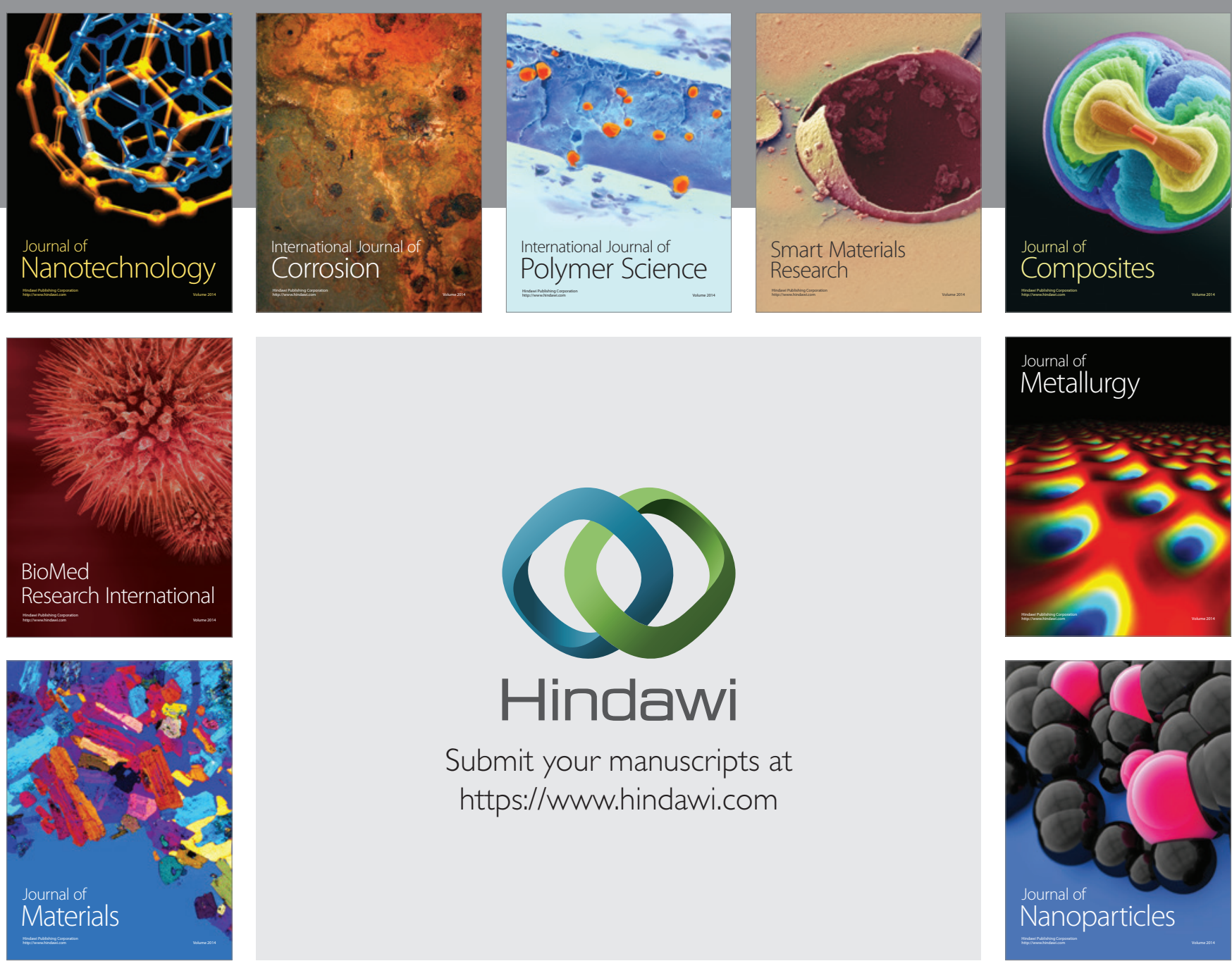

\section{Hindawi}

Submit your manuscripts at

https://www.hindawi.com

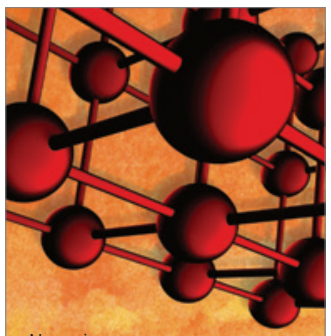

Materials Science and Engineering
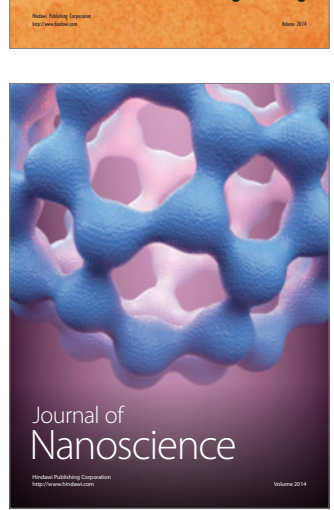
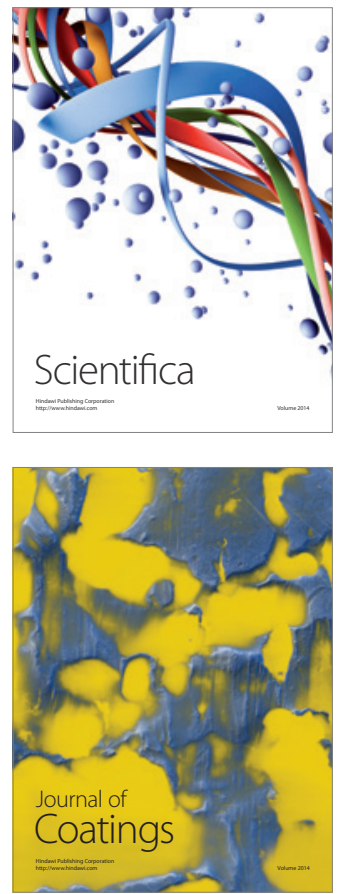
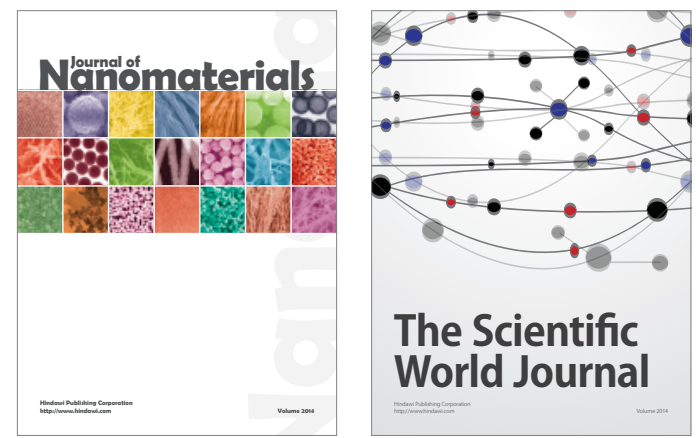

The Scientific World Journal
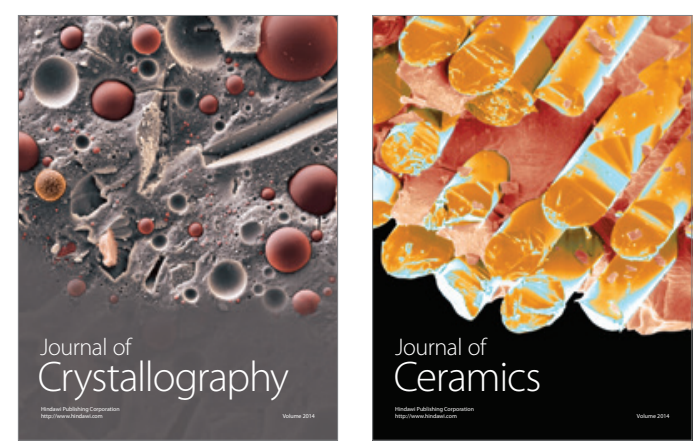
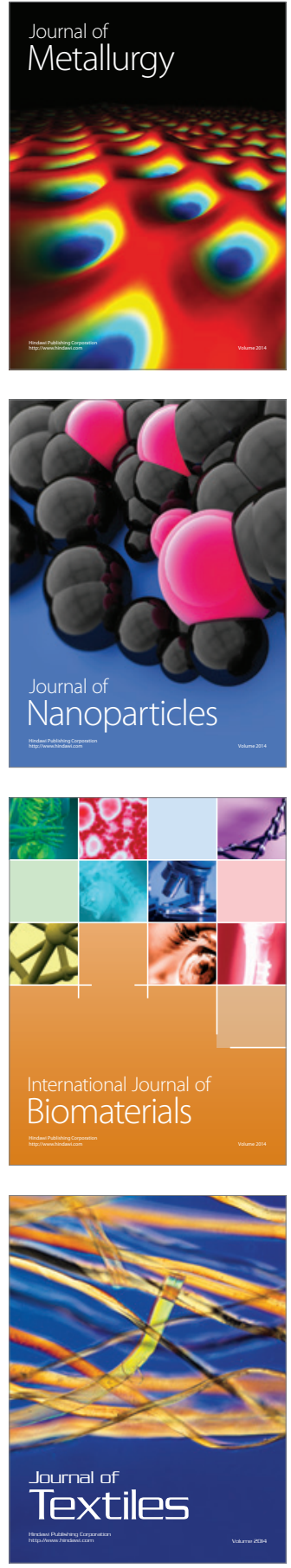